\title{
Less is More. Medieval Memory as Process of Creative Selection. An Introduction
}

There is neither the capacity nor a necessity to store everything that can be known. Information about the past in particular cannot be retained in its entirety.In order to be used and made fruitful in new circumstances it has to be organized, arranged and above all: selected. Data from the past accumulates in every generation until it is no longer manageable and understandable; the past becomes a burden. In this sense, the process of selection must be regarded as the fundamental moment - the Urszene - of making History, that is, the selection and transformation of an incoherent series of data from the past into coherent historical narratives. Yet selection is not only a rational and intentional process that reduces information: it also implies the unlikely survival of the most condensed texts. Above all, the process of selection depends on many incalculable factors, such as the author who takes decisions to reduce and arrange information, the audiences being guided by their own interests and the media and material transmission. In all three fields, creativity plays an important role, when details from the past are chosen to form part of the reservoir of knowledge for the next generation.

The Middle Ages present an especially extensive field of examples, where contemporary authors and political decision-makers used historical memory for their own purposes. They reduced the material available in order to make the vast 'halls of memory' manageable and manoeuvrable for their own times. In selecting, they made arguments from the past more effective and convincing: less is more. However, selection was many faceted, as it was used to defend or define tradition, consolidate or challenge power, validate or question perspectives, create or deconstruct legitimizing links to the past that have an impact on the future. The right selection of elements could be used as an argumentative base for one side or another.

The handling of historic details by medieval authors has always attracted interest. Authors' manipulation of the past has been analysed as well as their authenticity and reliability, their narrative strategies and even qualities as managers of collective memories and forgers. In 1994, however, a new perspective was established with Patrick Geary's Phantoms of Remembrance. His book was an attempt to understand the complex process of constructing memory through non-linear, irrational and subjective means, to "retrieve all sorts of information that together provide the referential field within which to experience and evaluate their daily experiences and to prepare for the future." Various authors and genres have since been reassessed in the light of

1 Patrick J. Geary, Phantoms of Remembrance. Memory and Oblivion at the End of the First Millennium, Princeton 1994, 28. 
Geary's focus on the subjective and even sentimental moments of creating memory, creativity, phantasy and even the allowance of phantoms.

By way of introduction, we want to emphasize the importance of the creative element within the selective strategies of the Early Middle Ages. An initial perspective is early medieval historiography and the creation of influential texts about the past. A second perspective is the creation of memory within one of the most influential institutions, the Papacy.

\section{Creative Selection in Narrative Perspective}

When producing narratives about the past - be it through historiography, monuments, even the narrationes in documents or any other medium of History - creators of historic fabric have always known more material and sources than they reproduced in their works. They selected their material carefully and - creatively. Metaphorically speaking, historical works can be compared to icebergs with only $15 \%$ visible and $85 \%$ hidden below the surface i.e. in references, footnotes or implications. The strength of an author is not to tell everything but the intended storyline. As we will see, medieval authors elaborated their truths often from authoritative pre-existing works. They did not copy everything but had to select, shorten and condense. Without massive manipulation, yet by way of intelligent and most creative selection they were able to find 'their' truths in the old texts, eventually contradicting the old texts. ${ }^{2}$ This is because to select means to make decisions about what to keep and what to omit. Only very few chroniclers of the Middle Ages admit their selective practice by using the straightforward term omissio. In prefaces and prologues they rather use formulations such as selectio, scinderatio, eligere, scarpere or, as Fredegar uniquely put it, sigillare. ${ }^{3}$ To medieval chroniclers, selection did not seem a topic to theorize about but rather to put into practice.

This certainly has to do with the fact that omissio and oblivio were closely related phenomena but disliked in general. Oblivion had the most negative image due to its uncontrollable and allegedly diabolical nature. What we know from the remaining writings from the Middle Ages - a highly selective collection of documents - is that forgetting was seen negatively. Forgetting damaged one of the most human characteristics, memoria. According to Augustine, human memory was of such an impor-

2 Herwig Wolfram, Einleitung oder Lügen mit der Wahrheit: Ein historiographisches Dilemma, in: Historiographie im frühen Mittelalter, ed. by Anton Scharer, Georg Scheibelreiter, Vienna etal. 1994, 11-25.

3 Fredegar, Chronicarum Fredegarii scholastici libri IV cum continuationibus, IV, prologue, ed. by Bruno Krusch, in: MGH SS rer. Merov. 2, Hanover 1888, 123: ... his quinque chronicis huius libelli nec plurima pretermissa siggyllatem congruentia stilo inserui, quod illi sollertissime absque reprehensionem condederunt. 
tance as God himself was to be found there. ${ }^{4}$ Oblivion in turn distanced man from his self as well as from God. Even our modern fear of Alzheimer's still transmits these negative notions about oblivion as deficiency of memory and the loss of self.

It is therefore not surprising that medieval historians distance themselves in prologues and argumentative passages from the accusation of neglectful oblivion or even intentional omission. Be it late antique authors such as Eusebe, Orose, early medieval historiographers such as Gregory of Tours, Einhard, Thietmar of Merseburg or later writers, they all formulate a necessity to avoid omission and express their vision of historiographical "pursuit of completeness". 5 The famous curse of Gregory of Tours in book 10 explicitly includes the demand that later authors should refrain from omitting or rewriting material from his chronicle. ${ }^{6}$ Ironically, only few medieval historiographers have been rewritten and used selectively like him. In the historiographical Fredegar collection, finalized in the 660s, almost $85 \%$ of Gregory's material was discarded, counting the lines in the MGH-edition. ${ }^{7}$ That means only $15 \%$ surfaced - we remember the iceberg. Gregory was forced under the surface, while the creative selection in the Fredegar collection used the gaps and lacunae to construct a completely new history.

All this is not new. The function of oblivion has been elaborately shown by Patrick Geary in his 1994 book Phantoms of Remembrance. Memory and Oblivion at the End of the First Millennium. Today, more than two decades later, these ideas are still relevant and it is time to reflect again on one of the central topics in the book: creative selection and the importance of forgetting. The warnings of his colleagues and the anonymous reviewer did not prevent Patrick Geary from touching on such an ephemeral and methodically difficult phenomenon. ${ }^{8}$ The reviewer was of the conviction that writing about "scanty records" would be nothing more than trying to make ex silentio assertions. If Patrick Geary wanted to write on "structures of forgetting" the reviewer counselled: "Forget it." Yet he or she was only a reviewer, and positi-

\footnotetext{
4 Augustinus, Confessiones X, 35, Sed ubi manes in memoria mea, Domine, ubi illic manes?; cf. Gerard J. P. O'Daly, Remembering and Forgetting in Augustine, Confessions X., in: Memoria - Vergessen und Erinnern, ed. by Anselm Haverkamp et al., Munich 1993, 31-46.

5 Peter Johanek, Die Wahrheit der mittelalterlichen Historiographien, in: Fritz Peter Knapp, Manuela Niesener (eds.), Historisches und fiktionales Erzählen im Mittelalter, Berlin 2002, 9-25.

6 Gregory of Tours, Libri historiarum decem, X, 31, ed. by Bruno Krusch, Wilhelm Levison, in: MGH SS rer. Merov. 1,1, Hanover ${ }^{2} 1937-1951,536$.

7 When it came to the vast number of episcopal episodes: from more than 200 bishops in medieval Gaul, he only mentioned eight in his book which was based on Gregory. Cf. also Gerald Schwedler, Lethe and "Delete”. Discarding the Past in the Early Middle Ages. The Case of Fredegar, in: Collectors' Knowledge. What is Kept, What is Discarded = Aufbewahren oder wegwerfen. Wie Sammler entscheiden, ed. by Anja-Silvia Goeing et al., Leiden 2013, 71-96; Gerald Schwedler, Vergessen, Verändern und Verschweigen. damnatio memoriae im frühen Mittelalter, Cologne 2021 (Zürcher Beiträge zur Geschichtswissenschaft 9), 282-285.

8 Geary, Phantoms of Remembrance (note 1), xiii-xiv; cf. the French translation: La mémoire et oubli à la fin du premier millénaire, trad. par Jean-Pierre Ricard, Paris 1996.
} 
vism was much stronger these days. In the meantime, the Phantoms of Remembrance were well received, and numerous other books and articles have appeared, focussing on forgetting and oblivion in the Middle Ages. ${ }^{9}$ They refer to Patrick Geary's reflections that stand at the beginning of a growing field of oblivion studies. Like dwarfs on the shoulders of giants, as Bernhard of Chartres put it (1120), it is possible to see further. The view from Patrick Geary's shoulders - broad shoulders indeed - opens the horizon and gives a wide perspective to approach medieval societies and how they dealt with the phenomena of forgetting. And to add a small personal note, it was a vital experience for me, when I first read the 'Phantoms'. Patrick Geary demonstrated that to understand the workings of medieval memory, it was important to know but eventually leave the path of Maurice Halbwachs, Pierre Nora and Jan and Aleida Assmann and to reverse the perspective. ${ }^{10}$ The fluidity of memory, that is temporal or permanent ignorance, as well as its relevance of individual and collective identity needed a historical perspective, not only the sociologists' view. From this angle, oblivion studies are concerned with social contexts on the one hand and with orders of knowledge, Wissensgeschichte on the other.

The Phantoms of Remembrance of the first millennium have led to new insights through the publication in 1994 and yet have furthered the understanding of dealing with losses in the field of Memory. Recent studies for the early Middle Ages have brought about a wholly new perspective on the usage of the past, ${ }^{11}$ especially for the time of the Carolingians. ${ }^{12}$ The perception grew that the past was practically 'manufactured' for the present, in order to change, underline or legitimize the one or the other perspective. ${ }^{13}$ Above all, Patrick Geary emphasized the high level of re-

9 Still more interested in memoria than oblivio despite their titles: Cosimo Damiano Fonseca, "Memoria" e "oblivio": orizzonte concettuale e riflessione storiografica, in: Memoria, ed. by Michael Borgolte, Cosimo Damiano Fonseca, Hubert Houben, Bologna, Berlin 2005, 11-20; Johannes Fried, Erinnerung und Vergessen; Die Gegenwart stiftet die Einheit der Vergangenheit, in: Historische Zeitschrift 273 (2001), 561-593.

10 Geary, Phantoms of Remembrance (note 1), 10-11.

11 Helmut Reimitz, History, Frankish Identity and the Framing of Western Ethnicity (550 - 850), Cambridge 2015; Maximilian Diesenberger, Helmut Reimitz, Zwischen Vergangenheit und Zukunft. Momente des Königtums in der merowingischen Historiographie, in: Das frühmittelalterliche Königtum. Ideelle und religiöse Grundlagen, ed. by Franz-Reiner Erkens, Berlin 2005, 214-269, esp. 242-245; The Resources of the Past in Early Medieval Europe, ed. by Clemens Gantner, Rosamond Mc Kitterick and Sven Meeder, Cambridge 2015; for general Kimberly Rivers, Memory and History in the Middle Ages, in: Writing the History of Memory, ed. by Stefan Berger, Bill Niven, London 2014, 47-64.

12 In general cf. the important study of Rosamond McKitterick, History and Memory in the Carolingian World, Cambridge 2004; also Geoffrey Koziol, The Politics of Memory and Identity in Carolingian Royal Diplomas. The West Frankish Kingdom (840 - 987), Turnhout 2012 (Utrecht studies in medieval literacy 19); Mayke De Jong, The Resources of the Past: Paschasius Radbertus and his Epitaphium Arsenii, in: Exzerpieren. Kompilieren. Tradieren. Transformationen des Wissens zwischen Spätantike und Frühmittelalter, ed. by Stephan Dusil et al., Berlin 2017, 131-152.

13 Cf. the practice to read the narratives of 'annals' from the perspective of a later causa scribendi: Matthias Becher, Eid und Herrschaft. Untersuchungen zum Herrscherethos Karls des Großen, Sigmar- 
flection on oblivion among the medieval writers of history or documents. He made clear that contemporaries of the end of the first millennium were elaborate and partially more radical than various modern theories on oblivion. One of the most explicit medieval writers, who theorized about the need to forget, was Arnold of St Emmeram in Regensburg. In his hagiographic work on the Miracles of St Emmeram, which he wrote as provost of that monastery in Regensburg shortly after 1036, he stated: "Not only is it proper for the new things to change the old ones; if the old ones are disordered they should entirely be thrown away; yet if they conform to proper order of things but are of little use, they should be buried with reverence."14

Few medieval and modern thinkers are so explicit about leaving the past behind. Nonetheless, Arnold's uncompromising readiness to leave the past behind, highlighted by Patrick Geary in his work, has so far not entered the theories dealing with oblivion in history: in 'Memory studies', the research canon includes scholars from Halbwachs, Nora, Oexle and Assmann and operates with models from Cicero and the rhetorica ad Herennium. ${ }^{15}$ On the other side 'Oblivion studies' are not established as institutionalized research perspectives and refer to a much smaller base of theoretical concepts. For various reasons, most of the earlier prominent writers on forgetting are rarely quoted, be it Francis Bacon, Friedrich Nietzsche or Michel Foucault. Such authors share Arnold's radical embracement of forgetting. Yet the theme of forgetting is still neglected in memory studies. ${ }^{16}$ There still seems to be the bias that ob-

ingen 1993 (VuF. Sonderband 39); Rosamond McKitterick, Constructing the Past in the Early Middle Ages. The case of the Royal Frankish Annals, in: Transactions of the Royal Historical Society, Ser. 6, vol. 7, 1997, 101-129; Yitzhak Hen, The Annals of Metz and the Merovingian Past, in: The Uses of the Past in the Early Middle Ages, ed. by Yitzhak Hen, Matthew Innes, Cambridge 2000, 175-190; On the aspect of 'manufacturing' a past for the present: forgery and authenticity in medievalist texts and objects in nineteenth-century Europe, ed. by János M. Bak, Patrick J. Geary, Gábor Klaniczay, Leiden 2015 (National cultivation of culture 7). Cf. also Manufacturing Middle Ages: Entangled history of medievalism in nineteenth-century Europe, ed. by Patrick J. Geary, Gabor Klaniczay, Leiden 2013 (National cultivation of culture 6).

14 Arnold von St. Emmeram, De miraculis beati Emmerami liber unus et De memoria beati Emmerami et eius cultorum alter liber, ed. by Georg Heinrich Pertz, in: MGH SS 4, Hanover 1844, 547: non solum novis vetera licet mutare, sed etiam, si sint inordinata, penitus abiicere, sin vero ordinaria sed minus utilia, cum veneratione sepelire. See Geary, Phantoms of Remembrance (note 1), 7.

15 Maurice Halbwachs, La mémoire collective, Paris 1939; Maurice Halbwachs, Les cadres sociaux de la mémoire, Paris 1925. Pierre Nora (ed.), Les Lieux de mémoire, 3 vols., Paris 1984-1992; English translation: Rethinking France: Les Lieux de mémoire, vol. 1: The State, Chicago 1999; vol. 2: Space, Chicago 2006; vol. 3: Legacies, Chicago 2009; vol. 4: Histories and Memories, Chicago 2010. Jan Assmann, Das kulturelle Gedächtnis. Schrift, Erinnerung und politische Identität in frühen Hochkulturen, Munich 1999.

16 Gadi Algazi, Forget Memory. Some Critical Remarks on Memory, Forgetting and History, in: Damnatio in Memoria. Deformation und Gegenkonstruktionen in der Geschichte, ed. by Sebastian Scholz, Gerald Schwedler, Kai-Michael Sprenger, Cologne, Weimar, Vienna 2014 (Zürcher Beiträge zur Geschichtswissenschaft 2), 25-34; Lucie Doležalová, Tamás Visi, Revisiting Memory in the Middle Ages, in: The Making of Memory in the Middle Ages, ed. by Lucie Doležalová, Leiden, Boston 2010, $1-8$. 
livion is negative in itself, be it Umberto Eco with his article An Ars oblivionalis? Forget it! or Harald Weinrich with his study Lethe on forgetting in world literature and all those figureheads of the memory studies. ${ }^{17}$ Only few studies underline the importance of the man-made aspect of forgetting. ${ }^{18}$ Most recent works on forgetting, addressing themselves as exponents of obliviology, the study of oblivion, as for example the books of Oliver Dimbath in 2015 or Christine Abbt in 2016, have shown how important it is to combine critical theory of forgetting with historical examples. ${ }^{19}$

There is also another important aspect that Patrick Geary pointed out and which would be scrutinized later on by generations of researchers. Geary analysed the logics behind Arnold's suggestion to waste and bury history. The categories that Arnold emphasized to made selections were "order" and "usefulness". ${ }^{20}$ It was the aspect of the usage of the past that proved most productive. ${ }^{21}$ Despite the many titles of literature on memory and the uses of the past in the Middle Ages, to which modern researchers have contributed their share of pages, there are still many open questions. Yet, it has become clear that there is no general key to explain the aim and practice of historiography. Late antique and medieval authors used their pasts in many different ways, exploiting them for ideas and arguments in order to shape identities and communities. ${ }^{22}$ In fact, recent research on historiography has focused not only on interdependencies and intertextual strategies but also on rewriting and compilation. ${ }^{23}$

Within the current interest in the uses of the past, the aspect of the abuse and manipulation of historiography came more to the centre of attention. ${ }^{24}$ Patrick

17 Eco, Umberto, An Ars Oblivionalis? Forget it!, in: Publications of the Modern Language Association, 1988, 254-261.

18 Harriet Isabel Flower, The Art of Forgetting. Disgrace and Oblivion in Roman Political Culture, Chapel Hill 2006.

19 Christine Abbt, “Ich vergesse”. Über Möglichkeiten und Grenzen des Denkens aus philosophischer Perspektive, Frankfurt am Main 2016. Oliver Dimbath, Oblivionismus. Vergessen und Vergesslichkeit in der modernen Wissenschaft, Konstanz 2014.

20 Geary, Phantoms of Remembrance (note 1), 7-8.

21 Carole Ellen Straw, Richard Lim (eds.), The past before us: the challenge of historiographies of late antiquity, Turnhout 2005; Yitzhak Hen, Matthew J. Innes (eds.), The Uses of the Past in the early Middle Ages, Cambridge 2000.

22 Walter Pohl, Veronika Wieser (eds.), Historiography and Identity I: Ancient and Early Christian Narratives of Community, Turnhout 2019.

23 Rosamond McKitterick, History and memory in the Carolingian world, Cambridge et al. 2004; Histoire et memoire dans le monde carolingien, Turnhout 2009; Walter Pohl, Historiography and Identity: Methodological Perspectives, in: Historiography and Identity I (note 22), 7-50; Peter van Nuffelen, Clavis Historicorum Antiquitatis Posterioris: an inventory of Late Antique historiography (A.D. $300-800)$, Turnhout 2019; the Clavis is based on the free database https://www.late-antique-historiography.ugent.be/database/.

24 Walter Pohl, Ian Wood, Introduction: cultural memory and the resources of the past, in: The resources of the past (note 11), 1-14; Kai-Michael Sprenger, The Tiara in the Tiber. An Essay on the damnatio in memoria of Clement III (1084-1100) and Rome's River as a Place of Oblivion and Memory, in: Reti Medievali 13/1, 2012, 153-174. 
Geary stipulated a strong argument with his statement that creativity and selectivity were of greater influence on the formation of medieval memory than thought before. It became clear that oblivion and manipulation as well as damnatio memoriae were central aspects for shaping and constructing individual and collective pasts. Yet the metaphor of the 'phantoms' as a phenomenon of vague and at the same time productive knowledge has not fully been exploited by research. To allow even more room for a positive evaluation of forgetting in the context of creative selection, it might be useful to present some outlines here.

Forgetting is certainly not the dark side of memory, in the way ignorance may be seen as the opposite of knowledge. ${ }^{25}$ The difference is the elapse of time, producing not clear borders but vague zones of knowledge and half-knowledge, fantastically encapsulated in the word 'phantoms'. The power of the concept of forgetting lies in the fact that it is an ambiguous idea to indicate the precarious nature of memory and knowledge. Memory is ephemeral and prone to change and manipulation. However, there is wide agreement within memory studies that oblivion can be observed on an interpersonal level and therefore is a historical phenomenon. ${ }^{26}$ Oblivion becomes visible, if at all, only from an ex-post perspective or from external sources. This means that the most fruitful approach to analyse oblivion is - despite the abundance of literary and sociological studies - the historical approach. Yet to delineate oblivion, it is important to refer to it in the epistemological categories. One can speak of specified oblivion, if an epistemic process took place whereby the borders between known and unknown were defined. This makes it possible to historicize oblivion, to analyse it as an entity that evolves and changes over time. ${ }^{27}$

Nevertheless, the concept of oblivion as an object of study also opens up the analysis of contexts in which contemporaries were ready to forget freely and times when the general atmosphere was to gather and treasure knowledge from the past. These conjunctures of oblivion are not necessarily parallel to great social changes such as floods, earthquakes and natural catastrophes or wars, epidemics and vast migration movements such as the Völkerwanderung. As it seems, the surroundings most inimical to medieval memory were renaissance and reform movements. It can be observed with the reform of the late Merovingian period, the renaissance of the Carolingian times or as Patrick Geary demonstrated, the renaissance of the 12th century. "Back-to-the-roots movements" had and have the attitude to unroot more than they protect. ${ }^{28}$

25 Gerald Schwedler, Kai-Michael Sprenger, Remembering and Forgetting, in: A Cultural History of Memory. The Middle Ages, ed. by Gerald Schwedler, London 2020, 147-163.

26 Cornel Zwierlein, Introduction: Towards a History of Ignorance, in: The Dark Side of Knowledge. Histories of Ignorance, 1400 to 1800, ed. by Cornel Zwierlein, Leiden 2016, 1-52, here 1.

27 Gerald Schwedler, Was heißt und zu welchem Ende untersucht man damnatio in memoria?, in: Damnatio in memoria (note 16), 9-24.

28 Constance Bouchard, An Age of Forgery, in: Rewriting Saints and Ancestors, Pennsylvania 2014, $63-86$ 


\section{Phantoms of remembrance in Papal Perspective}

Patrick Geary presented basic considerations on how to deal with knowledge about the past and the construction of the past. In doing so, fundamental phenomena in dealing with the past became visible, which are valid for all epochs and also for the present time. They crystallize, among other things, in the questions of how the tradition of the past is preserved, who preserves it, who erases it and who can change it. These questions are central because power and authority over memory have always been important to political and religious leaders. It could be a matter of shaping memory in such a way that it became suitable for one's own self-understanding and demands. The construction of the past was and is a way of constructing the present in order to bring past and present into accord. There are therefore two levels that must be taken into account when dealing with memory. First, there is the history of memory, i.e. all questions concerning the handling of memory; and secondly, the content of memory. That is, which memory was transported, preserved, changed or erased.

The preoccupation with the first level, the history of memory, is a preoccupation with propaganda, with the question of deciding what to remember and how to remember it. But it is also an engagement with the intellectual traditions in which memory was understood and cultivated. Depending on the sources, it is possible to find out what people thought about the past, what memory techniques they used, and in which structures memory was preserved, organized and recalled. At this point the two levels intertwine. For the way in which the past is stored influences the process of how one remembers. A change in the way memory is stored influences its content. Thus, the content of the memory depends on the structures with whose help memories of all kinds are mediated, newly created or changed. The content of memory is therefore subject to a dynamic process and is altered by every change in the structures in which it is incorporated. The content of memory is thus strongly determined by the circumstances of time and external conditions. As a result, the content of memory can be changed, simplified, reinterpreted or even eliminated relatively quickly.

Patrick Geary considered all these elements to be particularly interesting for the 11th century, especially since it was here that the model for the development of high medieval society was created. The model of the culture of remembrance that he has designed, as I have just outlined, can of course be applied in principle to all epochs. In each case it can help us to understand the contemporary approach to memory and of course this also means to understand the existing tradition - and thus allows us a new access to the sources. We will see how the access to the sources developed by Patrick Geary can be used for very different times and groups of sources.

Based on the approach of Patrick Geary, we would like to refer to the phenomenon of creative selection in the context of papacy. This question has always been of fundamental importance for the history of the pope: how is the tradition of the past preserved, who preserves it, who can change it or erase it. Yet, the construction 
of tradition has been a reflected process in Christian thinking ever since. Long before the slogan "invention of tradition" was coined, implying the uncovering of a new perspective, the key concepts for making tradition, quod ubique, quod semper, quod ab omnibus have been accepted for one and a half Millennia. ${ }^{29}$

As an example, we would like to use the letter of Pope Julius I, that he probably sent to the bishops of the East in 341, and that was handed down in the second apology of Athanasius. In the letter, written in Greek, Julius informed a group of bishops in the east of the empire that at a Roman synod, which probably took place in Rome in the spring of 341, Athanasius of Alexandria, Marcellus of Ancyra and other expellees had been accepted into the community of the Roman Church. With this decision, however, the Roman synod defied the judgment of the Synod of Tyre, which had deposed Athanasius in 335. The background and the complicated situation in which Julius' letter was written need not be dealt with here. ${ }^{30}$ What is important is that especially one passage of the papal letter was taken up by the church historians Socrates and Sozomenos in the 5th century. Julius had written:

But if there was an offence at all, the judgement had to be pronounced according to the rules of the Church, but not in the way it was pronounced. It had to be written to all of us, so that what is just could be determined by all. For it was Bishops who suffered injustice, and it was not arbitrary Churches that were affected, but those who were personally led by the Apostles. Why was it not written to us especially about the Alexandrian Church? Or do you not know that it was the custom that it was written to us beforehand and that it is from here that we determine what is just? So if there was such a suspicion against the bishop there, it had to be written to the church here. $^{31}$

Socrates and Sozomenos interpreted this passage in such a way that "without the judgement of the Roman bishop" no valid judgement could be passed in the church. ${ }^{32}$ And in the 6th century the church historian Cassiodor wrote in his Historia tripartita that "the church rule certainly commands that synods may not be celebrated without the verdict of the Roman bishop." 33 The pro-Roman tendency of the authors mentioned had thus formulated from the draft a claim which was not at all con-

29 Vinzenz von Lérins, Commonitorium 2,5, ed. by Claudia Barthold, Michael Fiedrowicz, Mülheim 2011, 186: In ipsa item catholica ecclesia magnopere curandum est, ut id teneamus quod ubique, quod semper, quod ab omnibus creditum est.

30 Myron Wojtowytsch, Papsttum und Konzile von den Anfängen bis zu Leo I. (440 - 461), Stuttgart 1981 (Päpste und Papsttum 17), 95-104.

31 Athanasius, Apologia secunda 35,3-5, ed. by Hans-Georg Opitz, in: Athanasius Werke 2,1, Berlin 1938, 112-113.

32 Socrates, Historia ecclesiastica II, 17, ed. by Manja Širinjan, Günther Christian Hansen, in: Die griechischen christlichen Schriftsteller. Neue Folge, vol. 1, Berlin 1995; Sozomenos, Kirchengeschichte III, 10, 1, ed. by Joseph Bidez, Günther Christian Hansen, in: Die griechischen christlichen Schriftsteller. Neue Folge, vol. 4, Berlin 1960, 113.

33 Cassiodor, Historia tripartita IV, 9, 4, ed. by Walter Jacob, Rudolf Hanslik, in: Corpus Scriptorum Ecclesiasticorum Latinorum 71, Vienna 1952, 165. 
tained in the draft, but which was generally represented by the Roman bishops in the 5th and 6th century. Since the Greek original of the letter was hardly available in the West, Cassiodor's Historia Tripartita, a Latin translation and summary of the Greek works of Sozomenos, Socrates and Theodoret, now became the decisive carrier of memory, already carrying a deformed memory. ${ }^{34}$

Pseudoisidor used this work in particular for his forgeries, as Klaus ZechielEckes found out in his groundbreaking studies. In the Pseudoisidoric forgeries, however, the whole Julius letter is included. But it is by no means a translation from the Greek original, but a completely newly constructed letter. Pseudoisidor used the information he found with Cassiodor about the case of Athanasius and the role of Julius in this case. In a detailed analysis, Klaus Zechiel-Eckes has shown how Pseudoisidor fabricated his Julius letter from Cassiodor"s Historia Tripartita, from genuine papal letters and other sources ${ }^{35}$ :

"Therefore I am astonished that you are so bold and act so unwisely and attack the jurisdiction and rights of St. Peter, the Prince of the Apostles. In fact, it is the mark of his right, as has been said above, that without the authority of this Holy See no one may hold a Synod or call Bishops to a Synod or condemn them and expel them from their Episcopal seats or appoint others in their place, and you have not been afraid to violate all this. That all Bishops who are harassed and accused in any serious case, as often as necessary, may appeal to the Apostolic See at will and take recourse to it as if to a mother, so that they may be piously supported, defended and acquitted by it, as it has always been. The ancient authority of the Apostles and canons has reserved all the more important ecclesiastical matters and judgments concerning Bishops for the decision of the Apostolic See, since it is the Bishops who are rebuked for acting against their brethren in a manner different from that which is pleasing to the Pope in that chair." ${ }^{36}$

Pseudoisidor used his information about the changeable fate of Athanasius and the dogmatic controversy about the validity of the decisions of the Council of Nicaea to es-

34 Wojtowytsch, Papsttum (note 30), 104-105.

35 Klaus Zechiel-Eckes, Ein Blick in Pseudo-Isidors Werkstatt. Studien zum Entstehungsprozess der falschen Dekretalen. Mit einem exemplarischen editorischen Anhang (Pseudo-Julius an die orientalischen Bischöfe, JK +196), in: Francia 28,1 (2001), 37-90.

36 Zechiel-Eckes, Ein Blick in Pseudo-Isidors Werkstatt (note 35) 75-76: Quare miror vos tam audaces esse et tam impudenter egisse et terminos ac iura beati Petri apostolorum principis invasisse. Sui enim, ut paulo superius praelibatum est, iuris erat, ut absque eius sanctae sedis auctoritate nullus deberet aut concilia celebrare aut episcopos ad synodum convocare vel eos damnare aut propriis pellere sedibus aut alios in eorum loco ordinare, quae omnia vos temerare non timuistis. ... Ut omnes episcopi, qui in quibusdam gravioribus pulsantur vel criminantur causis, quotiens necesse fuerit, libere apostolicam appellent sedem atque ad eam quasi ad matrem confugiant, ut ab ea, sicut semper fuit, pie fulciantur, defendantur et liberentur. Cuius dispositioni omnes maiores ecclesiasticas causas et episcoporum iudicia antiqua apostolorum eorumque successorum atque canonum auctoritas reservavit, quoniam culpantur episcopi, qui aliter erga fratres egerint, quam eiusdem sedis papae fieri placuerit; Translation S. Scholz. 
tablish a fundamental right of the Roman bishop to have a say in church proceedings and church organization. ${ }^{37}$ Here, the Bishop of Rome became the helper and protector of those bishops who were fighting for truth and justice and were persecuted, accused and deposed by unjust bishops. However, the letter and the wide circulation that the pseudo-isidoric decrees achieved also changed the memory of the episode in question. $^{38}$ That there had been a letter of Julius to the Eastern bishops could be deduced without doubt from Cassiodor. It was therefore not surprising that the letter appeared in a collection of old papal decrees. By including Pseudoisidor's knowledge about the trials of Athanasius and the controversy about the nicaenum, a credible document was created, since it corresponded with the information of Cassiodor in large parts. We therefore see as a history of memory how the Fälscherwerkstatt (forger's workshop), ${ }^{39}$ which was based in Corbie and possibly also in other monasteries, dealt with the sources of tradition at its disposal and understood and cultivated memory in a very special way. We can also see how a completely new content of memory was created here, which finally had a massive impact in the High Middle Ages.

\section{What to expect from this book}

Any approach to the theme of creative selection will need a focus. It is hardly possible to aim at a handbook or anthology of neglected, discarded or deleted details in chronicles, of de-selected topics or biographies nor a list of selection strategies as a whole. Each historiographical situation brings about specific elements of selection. The collected papers in this book w approach this from individual perspectives offering insights into the different ways of dealing with knowledge from the past. They pursue the question of what happens to data if transmission is discontinued but still has effect on posterity.

By way of Augustinian retractatio Patrick Geary reflects on the Phantoms of Remembrance. Memory and Oblivion at the End of the First Millennium of 1994 and yet extends this with further considerations. He highlights that certain forms of knowledge are considered valuable particularly often and therefore have been more likely to be handed down and preserved. In the area of legal knowledge, for example, the emergence of the chartulary, which was intended to safeguard early medieval legal titles but often disposed of historically valuable material, should be highlighted here. He emphasizes that the forgetting of historical and legal knowledge should be of particular interest, since a 'cleansing' was continuously taking place and thus new images of medieval society were constantly emerging.

37 Gotthold Hartmann, Der Primat des römischen Bischofs bei Pseudoisidor, Stuttgart 1930, 65-66. 38 Zechiel-Eckes, Ein Blick in Pseudo-Isidors Werkstatt (note 35) 46-47.

39 Abigail Firey, Canon Law Studies at Corbie, in: Fälschung als Mittel der Politik? Pseudoisidor im Licht der neuen Forschung: Gedenkschrift für Klaus Zechiel-Eckes, ed. by Karl Ubl, Daniel Ziemann, Wiesbaden 2015 (MGH - Studien und Texte 57), 19-80. 
Walter Pohl notes that identities were created through 'historical memory' by people identifying with a group (micro/macro group) and trying to find their place in it. Historiographical but above all normative texts influenced this 'shaping of identity', which he proved with some early medieval authors, such as Beda Venerabilis, Gregory of Tours, Fredegar and Erchempert of Montecassino.

Ian Wood reveals arguments of how the biographical situation of an author changes his patterns of selection. If one compares the three works of Jonas of Bobbio, the Vita Vedastis, the Vita Iohannis and the Vita Columbani, which he wrote in different phases of his life, one can see modifications and different focal points represented in his written memory. With increasing age and growing importance within the church hierarchy, Jonas emphasized aspects such as authority and conformity to the rules of the respective protagonists.

Michael J. Kelly places oblivio as a specific method of the Visigothic historiographers, especially with Isidor of Seville, at the centre of his considerations. Isidor wanted to erase not only the Visigoth king Gundemar from memory, but also the Council of Toledo in 610, which he had called to organize the church. Here, a personal attitude led to the fact that Gundemar is not only practically absent from Isidor's work and therefore not in the derived sources. More important is that Gundemar is missing in the most important Spanish collection of canon law, the Collectio Hispana.

Philippe Depreux deals with creativity and selection at the Carolingian court. He compares various sources in which the royal entourage was recorded and can show that their historiographical mentioning had little to do with their actual importance at court. Later literary representation (or mis-representation) ranged from an explicit damnatio memoriae to manipulative selection, especially since lists, by their suggestive power, created arguments on which later claims could be built. Depreux concludes that each list has to be perceived as an individual case and for the explanatory models to be adapted to the manifold possibilities of dealing with memory.

Gerald Schwedler's contribution deals with creative strategies of selection in the work of Gregory of Tours and Fredegar. Both authors are suitable examples for the supposition that there can be no history without selection. Oblivio and omissio are essential organizational mechanisms to counteract a blockade by overstraining the knowledge systems. Especially in the work of Gregory of Tours one can find a set of text strategies with which historical knowledge was creatively selected and ordered.

The collaborative team of Michael Eber, Stefan Esders, David Ganz and Till Stüber dedicated their paper to the prominent Codex Remensis (Berlin, Staatsbibliothek, Phill. 1743), one of the most important early medieval collections of canon law. Yet this very manuscript shows that canon law was not only recorded in it, but actively changed through selection processes. Individual decisions and historical circumstances influenced legal knowledge, which was compiled around the middle of the 6th century, but took into account the entire Christian legal tradition. The manuscript includes council texts, treatises, lists of popes and church provinces as well as the Edict of Chlothar II of 614. But the collection shows as well that as early as the 
8th century the old Merovingian legislation was no longer considered a living legal life, but was in a sense 'frozen'.

Helmut Reimitz emphasized the scope for memory using the example of Carolingian genealogies. Genealogical texts were thus a conscious decision for one of many options. A certain genealogical diversity was possible. Queen Fredegunde had used the oath as a means to legitimize her son Clothar II. Only in the Carolingian period did manuscripts appear with genealogical lists in the sense of royal catalogues which were even handed down as part of legal collections.

Jörg Sonntag dealt with the connection between memory and religious life in the Middle Ages. He showed how monasteries functioned as places of remembrance, using the example of the regulations for foot washing (mandatum) and the common meal. This led to the imitation of biblical role models, through which one wanted to find eternal truth, one's own self was to be absorbed into the role (Mary Magdalene, Jesus, etc.), even a pious oblivion of self was striven for. In the Carthusian order, the aim was to regulate the forgetting of the institutional past by burning the registers every two years.

In his contribution, Manfred Groten opened the perspective on creative selection for the 12th century. In line with Geary's considerations on the phantoms of remembrance in $11^{\text {th }}$-century Regensburg, he analyses the high medieval perception of Charlemagne as well as the new model for the understanding of History as it was established by Otto of Freising in his historiographic works. These changes indicate the general transformation within the medieval mindset concerning not only the understanding of the individual but also the striving for order and community re-projected into the past.

In conclusion, Gordon Blennemann emphasized that for mechanisms of creative selection, the relationship between form and content, between writing and vocality, and between individual and group, had always stood out. The creative power of the individual is sometimes difficult to grasp, and aspects such as specialization, the role as an outsider, positions of power, hierarchies and above all conditions of transmission determine the classification. Blennemann underlines the concept of selection as a meaningful term: one could assume conscious and unconscious latent moments, which lead to the fact that the respective 'actual' state of relevant knowledge from the past is always changing. 
